\title{
Aksesibilitas Sumber Daya pada Usaha Peternakan Sapi Potong Rakyat
}

\section{Resource Accessibility in Beef Cattle Farming Business}

\author{
Amam $^{1 *}$, P. A. Harsita1, M. W. Jadmiko', \& S. Romadhona ${ }^{2}$ \\ ${ }^{1}$ Program Studi Peternakan, Fakultas Pertanian, Universitas Jember \\ ${ }_{2}^{2}$ Program Studi Ilmu Tanah, Fakultas Pertanian, Universitas Jember \\ Jl. Kalimantan 37 Jember, Jawa Timur, Indonesia \\ *Email korespondensi: amam.faperta@unej.ac.id
}

\begin{tabular}{lll}
\hline - Diterima: 07 Oktober 2020 & $\bullet$ Direvisi: 31 Oktober $2020 \quad$ • Disetujui: 07 Januari 2021 \\
\hline
\end{tabular}

\begin{abstract}
ABSTRAK. Keberlanjutan usaha ternak dan pengembangan usaha ternak tidak terlepas dari dukungan berbagai sumber daya. Tinggi dan rendahnya aksesibilitas peternak terhadap sumber daya dipengaruhi oleh berbagai faktor, diantaranya ialah SDM peternak. Penelitian ini bertujuan untuk mengkaji aksesibilitas sumber daya pada usaha ternak sapi potong rakyat berdasarkan kualitas SDM peternak. Penelitian dilakukan di Desa Petung, Kecamatan Curahdami, Kabupaten Bondowoso, Provinsi Jawa Timur. Desa Petung merupakan salah satu Desa Binaan Universitas Jember dalam Program Pengabdian Desa Binaan (PPDB) untuk pengembangan komoditas sapi potong rakyat. Narasumber (responden) ialah peternak sapi potong rakyat sebanyak 120 orang. Pengumpulan data menggunakan metode Focus Group Discussion (FGD), observasi, dan survei. Survei dilakukan menggunakan teknik wawancara dan pengisian kuisioner dengan skala likert. Analisis data menggunakan metode Partial Least Square (PLS) dengan program SmartPLS 2.0. Hasil penelitian menunjukkan bahwa kualitas SDM peternak berpengaruh pada akses peternak terhadap sumber daya finansial sebesar $32,4 \%$, sumber daya teknologi sebesar $35,2 \%$, dan sumber daya fisik sebesar $28,1 \%$. Kesimpulan penelitian menunjukkan bahwa kualitas SDM peternak memengaruhi akses terhadap sumber daya finansial dan teknologi secara positif dan signifikan, namun tidak signifikan pada akses terhadap sumber daya fisik.
\end{abstract}

Kata kunci: Sapi potong, SDM, program PPDB

ABSTRACT. The sustainability of livestock farming business and livestock business development cannot be separated from the support of various resources. The high and low accessibility of farmers to resources is influenced by various factors, including the farmers' human resources. This research aims to assess the accessibility of resources in the beef cattle farming business based on the quality of the farmers' human resources. The research was conducted in Petung Village, Curahdami District, Bondowoso Regency, East Java Province. Petung Village is one of the Universitas Jember Assisted Villages in the Assisted Village Service Program or Program Pengabdian Desa Binaan (PPDB) for the development of community beef cattle commodities. Informants (respondents) were beef cattle farmers totaling 120 people. Collecting data using the method of Focus Group Discussion (FGD), observation, and surveys. The survey was conducted using interview techniques and filling out a questionnaire with a likert scale. Data analysis used the Partial Least Square (PLS) method with the SmartPLS 2.0 program. The results showed that the quality of the farmers' human resources had an effect on farmers' access to financial resources by $32.4 \%$, technological resources by $35.2 \%$, and physical resources by $28.1 \%$. The conclusion of the research shows that the quality of the farmers' human resources affects access to financial and technological resources positively and significantly, but not significantly on access to physical resources.

Keywords: Beef cattle, HR, PPDB program

\section{PENDAHULUAN}

Peraturan Pemerintah (PP) Republik Indonesia Nomor 6 tahun 2013 tentang Pemberdayaan Peternak menjelaskan pemberdayaan peternak merupakan segala bentuk (upaya) yang dilakukan oleh pemerintah, pemerintah provinsi, pemerintah kota/kabupaten, serta pemangku kepentingan di bidang peternakan dan kesehatan hewan dengan tujuan untuk meningkatkan kemandirian, memberikan kemudahan dan kemajuan usaha, serta meningkatkan daya saing dan kesejahteraan peternak. Salah satu 
upaya pemberdayaan peternak ialah melalui penguatan kelembagaan peternakan sebagai wadah pemberdayaan peternak (Soetriono dan Amam, 2020), khususnya kelompok peternak binaan (Amam dan Harsita, 2019a), sebab kelembagaan peternakan berperan dalam upaya pengembangan usaha ternak (Amam dan Soetriono, 2019) dan juga dapat berperan untuk meningkatkan SDM peternak (Amam dan Harsita, 2019b).

Keberlanjutan usaha ternak dan pengembangan usaha ternak tidak terlepas dari dukungan berbagai sumber daya (Amam et al., 2019a; 2019b; 2019c). Tinggi dan rendahnya aksesibilitas peternak terhadap sumber daya dipengaruhi oleh berbagai faktor (Amam et al., 2020a), diantaranya ialah SDM peternak (Amam dan Soetriono, 2020). Semakin tinggi akses peternak terhadap sumber daya, maka semakin besar peluang pengembangan usaha ternak (Amam et al., 2019d; 2019e). Sumber daya yang mendukung usaha peternakan diantaranya ialah sumber daya finansial, sumber daya teknologi, dan sumber daya fisik (Amam et al., 2019f). Usaha peternakan juga didukung oleh sumber daya ekonomi, sumber daya lingkungan, dan sumber daya sosial (Amam et al., 2019g).

Berbagai upaya pengembangan usaha ternak sapi potong di Indonesia telah banyak dilakukan oleh pemerintah untuk mewujudkan swasembada daging nasional. Upaya tersebut difokuskan pada pembenahan sektor hulu hingga hilir usaha ternak. Salah satu upaya tersebut diantaranya ialah modal pembiayaan Kredit Usaha Rakyat (KUR) dengan bunga rendah (7\%) dan grace periode maksimal 3 (tiga) tahun. Upaya lain diantaranya ialah Upaya Khusus Sapi Indukan Wajib Bunting (Upsus Siwab) yang telah dimulai sejak tahun 2017 sesuai dengan Permentan No. 48/2016 tentang Upaya Khusus Percepatan Peningkatan Populasi Sapi dan Kerbau Bunting.

Pemerintah juga mendorong investasi swasta dan Badan Usaha Milik Negara (BUMN) dalam hal penambahan induk sapi sesuai dengan Permentan No. 49/2016 tentang Pemasukan Ternak Ruminansia Besar ke dalam Wilayah Negara Republik Indonesia. Upaya lain ialah menetapkan kawasan sapi potong, kerbau, kambing, sapi perah, domba, dan babi secara nasional melalui Kepmentan No. $43 / 2015$.

Upaya-upaya tersebut tentunya juga mendukung pengembangan usaha ternak sapi potong rakyat, sebab usaha ternak sapi potong rakyat dengan skala rumah tangga dapat memberikan kontribusi sebesar 6,8\% terhadap total pendapatan rumah tangga peternak (Setiawan et al., 2014). Peternakan sapi potong rakyat juga berperan terhadap peningkatan perekonomian negara Indonesia, namun ironisnya usaha peternakan skala rumah tangga belum sepenuhnya berorientasi pada bisnis, sehingga jumlah kepemilikan ternak sedikit (Sunarto et al., 2016), itulah sebabnya pasokan daging sapi lokal dari peternakan rakyat tidak efisien (Widiati, 2014). Kondisi demikian juga terjadi di Desa Petung, Kecamatan Curahdami, Kabupaten Bondowoso, Provinsi Jawa Timur.

Desa Petung adalah salah satu dari 320 desa yang merupakan Desa Binaan Universitas Jember sesuai dengan Keputusan Rektor Universitas Jember Nomor 12716/UN25/KL/2018 tentang Desa Binaan Universitas Jember. Desa Petung merupakan salah satu desa yang diprioritaskan untuk pengembangan usaha ternak sapi potong mengingat banyaknya petani yang memelihara ternak sapi potong untuk penggemukan (fattening) dengan rata-rata kepemilikan sapi potong 1-3 ekor. Qinayah et al. (2017) menyebutkan semakin besar skala usaha ternak, maka semakin besar juga pendapatan peternak, juga dapat menekan aspek kerentanan dan risiko kerugian usaha ternak (Amam dan Harsita, 2019c).

Upaya mendukung pemberdayaan peternak dan pengembangan usaha ternak sapi potong di Desa Petung, tidak lepas dari tiga pilar usaha ternak. Amam dan Harsita (2019d) menyatakan terdapat tiga pilar usaha ternak, yaitu breeding, feeding, and management. Fokus pada pilar ketiga, yaitu manajemen, maka tujuan penelitian ini yaitu mengkaji aksesibilitas sumber daya pada usaha ternak sapi potong rakyat berdasarkan kualitas SDM peternak. Sumber daya berperan penting terhadap pengembangan usaha ternak (Amam et al., 2020b), dan yang dimaksud sumber daya 
dalam penelitian ini ialah sumber daya finansial, sumber daya teknologi, dan sumber daya fisik (Amam et al., 2020c). Keterbaruan (novelty) dari penelitian ini ialah menganalisis kualitas SDM peternak dan menemukan pengaruhnya pada akses peternak terhadap sumber daya pada usaha ternak sapi potong rakyat di Desa Petung.

\section{MATERI DAN METODE}

Lokasi penelitian dipilih secara purposive di Desa Petung, Kecamatan Curahdami, Kabupaten Bondowoso. Desa Petung merupakan salah satu Desa Binaan Universitas Jember dalam Program Pengabdian Desa Binaan (PPDB) sesuai dengan Keputusan Rektor Universitas Jember No. 12716/2018 tentang Desa Binaan Universitas Jember. Terdapat 320 Desa Binaan Universitas Jember yang salah satunya adalah Desa Petung sebagai desa untuk pengembangan komoditas peternakan.

Pengambilan data dilakukan dengan metode Focus Group Discussion (FGD), observasi, dan survei. Survei tersebut dilakukan dengan wawancara dan pengisian angket (kuisioner) berskala likert +1 hingga +5 . Responden penelitian ialah semua peternak sapi potong di Desa Petung yang melakukan usaha ternaknya secara mandiri (bukan sistem kemitraan bagi hasil atau profit sharing, seperti gaduhan dan paron contract), tercatat sebanyak 120 orang berdasarkan hasil sensus ternak dan survei peternak saat observasi di Desa Petung.

Variabel utama yang diamati dalam penelitian ini ialah SDM peternak $(X)$, sumber daya finansial $\left(Y_{1}\right)$, sumber daya teknologi $\left(Y_{2}\right)$, dan sumber daya fisik $\left(\mathrm{Y}_{3}\right)$. Indikator dari variabel tersebut diuraikan pada Tabel 1 dan hubungan antar-variabel ditampilkan pada Gambar 1.

Tabel 1. Variabel dan indikator penelitian

\begin{tabular}{|c|c|c|}
\hline Variabel & Indikator & Notasi \\
\hline \multirow{5}{*}{ SDM peternak $(X)$} & Pengetahuan dan keterampilan & $\mathrm{X}_{1.1}$ \\
\hline & Kesehatan peternak & $\mathrm{X}_{1.2}$ \\
\hline & Motivasi peternak & $\mathrm{X}_{1.3}$ \\
\hline & Kemampuan peternak dalam berbahasa & $\mathrm{X}_{1.4}$ \\
\hline & Pengalaman beternak & $\mathrm{X}_{1.5}$ \\
\hline \multirow[t]{16}{*}{ Sumber daya finansial $\left(\mathrm{Y}_{1}\right)$} & Pendapatan utama & $\mathrm{Y}_{1.1}$ \\
\hline & Pendapatan dari usaha ternak sapi potong & $\mathrm{Y}_{1.2}$ \\
\hline & Pendapatan dari usaha non peternakan & $\mathrm{Y}_{1.3}$ \\
\hline & Pendapatan dari usaha ternak lain & $\mathrm{Y}_{1.4}$ \\
\hline & Pendapatan total untuk kebutuhan hidup keluarga & $\mathrm{Y}_{1.5}$ \\
\hline & Jumlah tabungan & $\mathrm{Y}_{1.6}$ \\
\hline & Jumlah hutang & $\mathrm{Y}_{1.7}$ \\
\hline & Jumlah pelunasan hutang & $\mathrm{Y}_{1.8}$ \\
\hline & Kepemilikan pedet jantan & $\mathrm{Y}_{1.9}$ \\
\hline & Kepemilikan pedet betina & $\mathrm{Y}_{1.10}$ \\
\hline & Kepemilikan dara jantan & $\mathrm{Y}_{1.11}$ \\
\hline & Kepemilikan dara betina & $\mathrm{Y}_{1.12}$ \\
\hline & Kepemilikan sapi jantan dewasa & $\mathrm{Y}_{1.13}$ \\
\hline & Kepemilikan sapi betina dewasa & $\mathrm{Y}_{1.14}$ \\
\hline & Kepemilikan sapi bunting & $\mathrm{Y}_{1.15}$ \\
\hline & Jumlah kepemilikan sapi & $\mathrm{Y}_{1.16}$ \\
\hline \multirow[t]{6}{*}{ Sumber daya teknologi $\left(\mathrm{Y}_{2}\right)$} & Pemilihan bibit & $\mathrm{Y}_{2.1}$ \\
\hline & Teknologi pakan & $\mathrm{Y}_{2.2}$ \\
\hline & Kesehatan ternak & $\mathrm{Y}_{2.3}$ \\
\hline & Sistem perkandangan & $\mathrm{Y}_{2.4}$ \\
\hline & Manajemen penggemukan & $\mathrm{Y}_{2.5}$ \\
\hline & Manajemen pemasaran & $\mathrm{Y}_{2.6}$ \\
\hline Sumber daya fisik $\left(\mathrm{Y}_{3}\right)$ & Rumah tempat tinggal & $\mathrm{Y}_{3.1}$ \\
\hline
\end{tabular}




\begin{tabular}{llc}
\hline Variabel & & Notasi \\
\hline & Kandang ternak & $\mathrm{Y}_{3.2}$ \\
& Sarana transportasi & $\mathrm{Y}_{3.3}$ \\
& Sarana komunikasi & $\mathrm{Y}_{3.4}$ \\
& Sarana informasi & $\mathrm{Y}_{3.5}$ \\
& Listrik rumah tangga & $\mathrm{Y}_{3.6}$ \\
& Kepemilikan lahan & $\mathrm{Y}_{3.7}$ \\
& Penggunaan lahan & $\mathrm{Y}_{3.8}$ \\
& Ketersediaan air & $\mathrm{Y}_{3.9}$ \\
& Ketersediaan pakan & $\mathrm{Y}_{3.10}$ \\
\hline
\end{tabular}

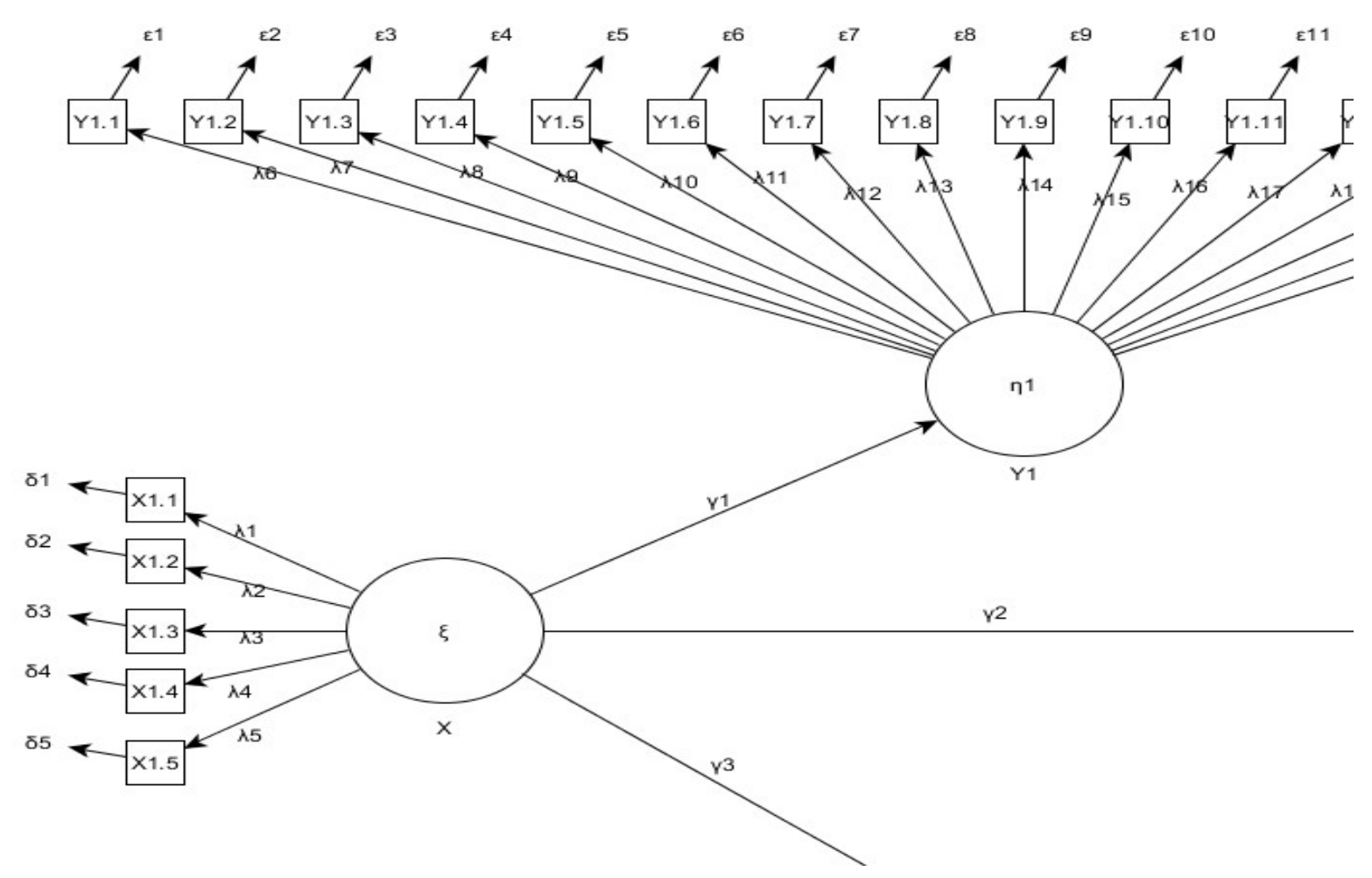

Gambar 1. Model hubungan variabel

Berdasarkan gambar di atas, pendekatan matematis untuk mengukur masing-masing indikator dengan menggunakan metode Partial Least Square (PLS) ialah sebagai berikut:

$$
X_{i}=\lambda x_{i} \xi_{i}+\delta_{i} ; Y_{i}=\lambda y_{i} \eta_{i}+\varepsilon_{i}
$$

Penggunaan metode PLS untuk analisis data digunakan sistem aplikasi Smart PLS 2.0. Wiyono (2011) menjelaskan salah satu keunggulan metode PLS ialah dapat memperkuat teori-teori yang masih lemah dan/atau dapat menemukan (merancang) teori baru. Metode PLS terdiri dari 2 (dua) langkah kerja, yaitu pengujian outer model dan pengujian inner model. Pengujian outer model setidaknya terdapat 4 (empat) macam kriteria, yaitu pengujian indikator (nilai outer loading), nilai Average Variance Extracted (AVE), nilai Cronbach's Alpha (CA), dan nilai Composite Reliability (CR). Pengujian inner model umumnya terdiri dari nilai koefisien determinasi $\left(R^{2}\right)$, nilai t-statistik, dan nilai koefisien parameter.

\section{HASILDAN PEMBAHASAN}

\section{Profil Desa Petung sebagai Desa Binaan Universitas Jember}

Desa Petung memiliki luas wilayah 1,59 $\mathrm{km}^{2}$ yang secara geografis terletak pada ketinggian $385 \mathrm{~m}$ dpl dengan curah hujan ratarata per tahunnya $364 \mathrm{~mm}$. Profil wilayah Desa 
Petung terdiri dari area persawahan $83 \mathrm{Ha}$, area tegalan $31 \mathrm{Ha}$, serta area bangunan dan pekarangan $45 \mathrm{Ha}$. Secara administrasi, Desa Petung terdiri dari 12 Dusun, 6 Rukun Warga (RW), dan 12 Rukun Tetangga (RT). Jumlah populasi penduduk sebanyak 3.308 orang yang terdiri dari 1.647 laki-laki dan 1.661 perempuan, sehingga kepadatan penduduk ialah 2.133 jiwa $/ \mathrm{km}^{2}$.

Potensi ternak sapi potong di Desa Petung didukung oleh ketersediaan lahan pekarangan yang luas (45 Ha) dan area tegalan (31 Ha).
Lahan tersebut bisa dioptimalkan sebagai media tanam hijauan pakan berupa rerumputan dan leguminosa. Daya dukung potensi ternak sapi potong juga didapat dari limbah pertanian berupa jerami, dedak, dan bekatul, tongkol jagung dan jagung afkir, serta limbah ubi kayu. Rusdiana et al. (2016) menyatakan ketersediaan hijauan pakan merupakan salah satu faktor penentu keberhasilan usaha ternak sapi potong. Hasil pemetaan wilayah Desa Petung ditampilkan pada Gambar 2.
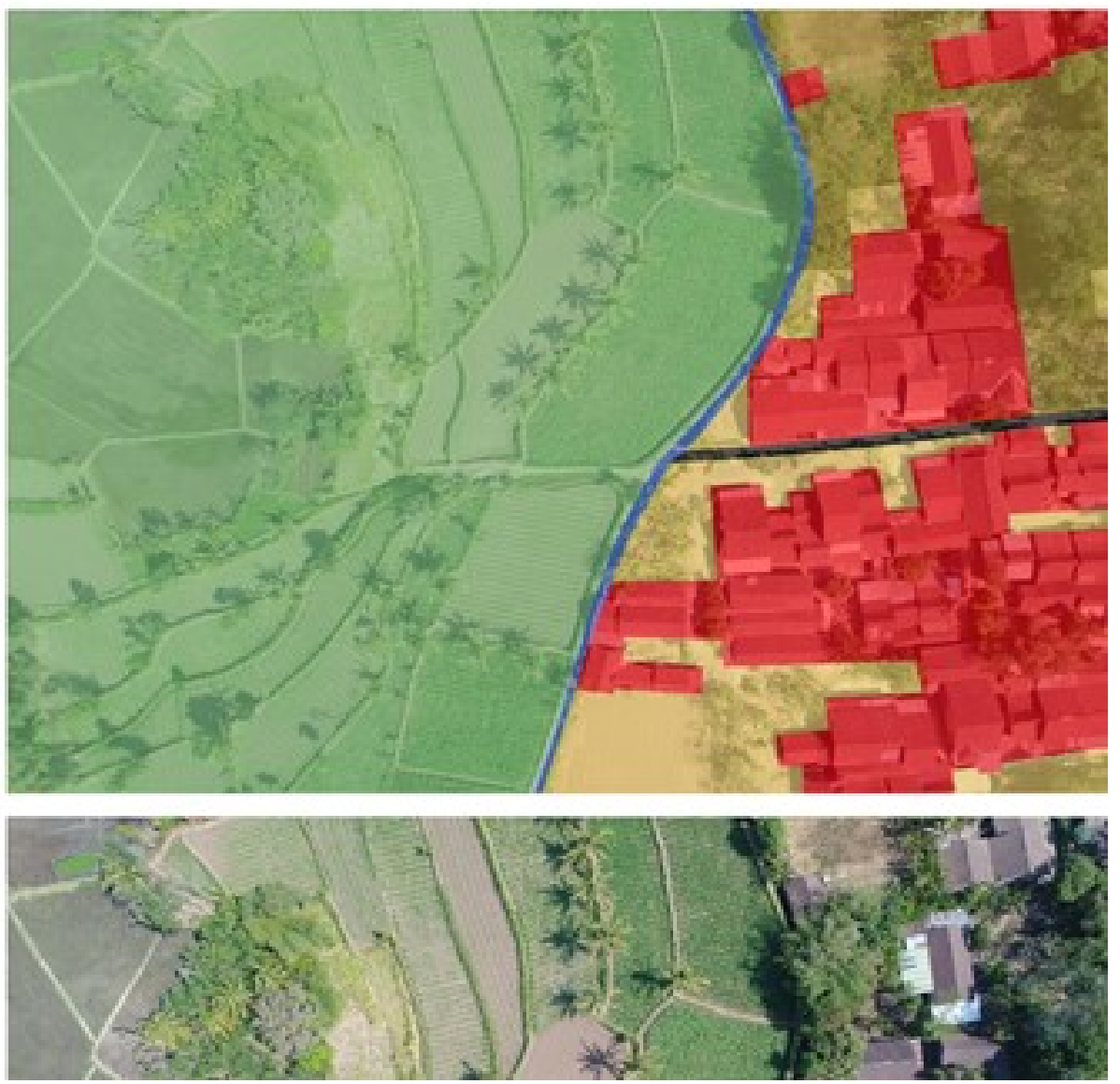

Gambar 2. Hasil pemetaan Desa Petung

Program Pengabdian Desa Binaan (PPDB) di Desa Petung secara khusus ialah upaya implementasi tiga pilar usaha ternak. Tiga pilar usaha ternak ialah breeding, feeding, and management (Amam dan Harsita, 2019d). Program PPDB di Desa Petung bertujuan: 1) tata kelola berbasis pembentukan dan penguatan kelembagaan peternakan; 2) pelayanan sosial dasar melalui pelaksanaan Program Sekolah Masyarakat Peternakan (SMP); 3) pengembangan ekonomi lokal berbasis komoditas unggulan yaitu sapi potong; 4) peningkatan kualitas lingkungan dengan konsep zero waste, yaitu pemanfaatan limbah tanaman untuk pakan dan pemanfaatan kotoran ternak untuk pupuk tanaman; serta 5) 
pemberdayaan perempuan melalui pendampingan program diversifikasi produk olahan daging sapi.

\section{Uji Outer Model}

Pengujian outer model pada metode Partial Least Square (PLS) setidaknya terdapat 4 (empat) macam kriteria, yaitu pengujian indikator (nilai outer loading), nilai Average Variance Extracted (AVE), nilai Cronbach's Alpha (CA), dan nilai Composite Reliability (CR). Hasil uji indikator (Tabel 1) dengan nilai outer loading ditunjukkan pada Tabel 3 dan hasil uji nilai AVE, CA, dan CR ditunjukkan pada Tabel 4.

Tabel 2. Hasil uji indikator

\begin{tabular}{|c|c|c|c|c|c|}
\hline Notasi & $X$ & $Y_{1}$ & $Y_{2}$ & $\mathrm{Y}_{3}$ & Keterangan \\
\hline $\mathrm{X}_{1.1}$ & 0,874 & & & & valid \\
\hline$X_{1.2}$ & 0,553 & & & & valid \\
\hline$X_{1.3}$ & 0,802 & & & & valid \\
\hline $\mathrm{X}_{1.4}$ & 0,508 & & & & valid \\
\hline $\mathrm{X}_{1.5}$ & 0,942 & & & & valid \\
\hline $\mathrm{Y}_{1.1}$ & & 0,716 & & & valid \\
\hline $\mathrm{Y}_{1.2}$ & & 0,823 & & & valid \\
\hline$Y_{1.3}$ & & 0,505 & & & valid \\
\hline $\mathrm{Y}_{1.4}$ & & 0,514 & & & valid \\
\hline $\mathrm{Y}_{1.5}$ & & 0,859 & & & valid \\
\hline $\mathrm{Y}_{1.6}$ & & 0,868 & & & valid \\
\hline$Y_{1.9}$ & & 0,715 & & & valid \\
\hline$Y_{1.10}$ & & 0,702 & & & valid \\
\hline$Y_{1.11}$ & & 0,866 & & & valid \\
\hline$Y_{1.13}$ & & 0,725 & & & valid \\
\hline$Y_{1.14}$ & & 0,718 & & & valid \\
\hline$Y_{1.15}$ & & 0,667 & & & valid \\
\hline$Y_{1.16}$ & & 0,942 & & & valid \\
\hline $\mathrm{Y}_{2.1}$ & & & 0,732 & & valid \\
\hline$Y_{2.2}$ & & & 0,629 & & valid \\
\hline $\mathrm{Y}_{2.4}$ & & & 0,506 & & valid \\
\hline $\mathrm{Y}_{2.5}$ & & & 0,718 & & valid \\
\hline$Y_{2.6}$ & & & 0,695 & & valid \\
\hline$Y_{3.2}$ & & & & 0,653 & valid \\
\hline$Y_{3.3}$ & & & & 0,664 & valid \\
\hline$Y_{3.4}$ & & & & 0,648 & valid \\
\hline$Y_{3.5}$ & & & & 0,611 & valid \\
\hline$Y_{3.7}$ & & & & 0,506 & valid \\
\hline$Y_{3.8}$ & & & & 0,724 & valid \\
\hline$Y_{3.9}$ & & & & 0,871 & valid \\
\hline$Y_{3.10}$ & & & & 0,879 & valid \\
\hline
\end{tabular}

Keterangan: Nilai outer loading setelah menghilangkan indikator tidak valid (valid >0,500)

Tabel 3. Hasil uji outer model

\begin{tabular}{lcccc}
\hline Variabel & Notasi & AVE & CA & CR \\
\hline$X$ & $X$ & 0,816 & 0,884 & 0,806 \\
$Y_{1}$ & $Y_{1}$ & 0,847 & 0,847 & 0,744 \\
$Y_{2}$ & $Y_{2}$ & 0,781 & 0,802 & 0,741 \\
$Y_{3}$ & $Y_{3}$ & 0,704 & 0,713 & 0,705 \\
\hline
\end{tabular}

\section{Uji Inner Model}

Pengujian inner model pada metode Partial Least Square (PLS) setidaknya terdapat 3 (tiga) macam kriteria, yaitu nilai koefisien determinasi $\left(\mathrm{R}^{2}\right)$, nilai t-statistik, dan nilai koefisien parameter. Hasil uji inner model pada Gambar 1 ditunjukkan pada Tabel 4. 


\section{Pengaruh SDM Peternak terhadap Akses Sumber Daya}

Sumber daya finansial, teknologi, dan fisik usaha ternak sapi potong di Desa Petung dipengaruhi oleh SDM peternak masing-masing sebesar $32,4 \%, 35,2 \%$, dan $28,1 \%$. Sumber daya finansial dipengaruhi SDM peternak secara positif dan signifikan (taraf signifikansi 5\%), artinya semakin tinggi SDM peternak maka akses terhadap sumber daya finansial semakin besar. Peternak yang memiliki SDM tinggi misalnya syarat pengalaman beternak sapi dan memiliki pengetahuan dan keterampilan umumnya memiliki akses sumber daya finansial yang tinggi, seperti tingginya pendapatan, kepemilikan ternak lebih dari 1 (satu) ekor, sehingga mampu mencukupi kebutuhan hidup keluarga, bahkan memiliki tabungan keluarga.

Tabel 4. Hasil uji inner model

\begin{tabular}{ccc}
\hline \multicolumn{1}{c}{ Pengujian } & Nilai & Keterangan \\
\hline Koefisien determinasi $\left(\mathrm{R}^{2}\right)$ & & \\
a. Sumber daya finansial & 0,324 & \\
b. Sumber daya teknologi & 0,352 & \\
c. Sumber daya fisik & 0,281 & \\
t-statistik & & \\
a. $X \rightarrow Y_{1}$ & 3,405 & signifikan \\
b. $X \rightarrow Y_{2}$ & 2,839 & signifikan \\
c. $X \rightarrow Y_{3}$ & 1,623 & tidak signifikan \\
Koefisien parameter & & \\
a. $X \rightarrow Y_{1}$ & 0,402 & pengaruh positif \\
b. $X \rightarrow Y_{2}$ & 0,314 & pengaruh positif \\
c. $X \rightarrow Y_{3}$ & 0,115 & pengaruh positif \\
\hline
\end{tabular}

Keterangan: $\mathrm{t}$ tabel: $1.657(\mathrm{~N}=120)$

Peningkatan SDM dapat mendukung pengembangan usaha peternakan sapi potong (Suresti et al., 2013). Salah satu upaya dalam mendukung pengembangan usaha peternakan ialah dengan sistem kemitraan agribisnis (Ashary, 2016), misalnya sistem kemitraan bagi hasil atau profit sharing seperti pola gaduhan atau paron contract (Amam et al., 2019g) dan kemitraan pola dagang umum (Amam et al., 2019i). Sistem kemitraan atau kemitraan usaha peternakan sesuai Permentan No. 13/2017 merupakan kerjasama antar-usaha peternakan atas dasar prinsip saling memerlukan, memperkuat, menguntungkan, menghargai, bertanggung jawab, dan ketergantungan. Ironisnya, peranan kelembagaan peternakan di Indonesia masih lemah dan belum cukup optimal (Arifin dan Riszqina, 2016).

Sumber daya teknologi dipengaruhi SDM peternak secara positif dan signifikan (taraf signifikansi 5\%), artinya semakin tinggi SDM peternak maka akses terhadap sumber daya teknologi semakin besar. Peternak yang memiliki SDM tinggi misalnya syarat pengalaman beternak sapi dan memiliki pengetahuan dan keterampilan umumnya memiliki akses sumber daya teknologi yang tinggi, seperti mampu memilih bibit, mampu mengolah pakan ternak, paham perkandangan, paham cara menggemukan sapi, dan paham manajemen pemasaran sapi (Amam et al., 2019f; Amam et al., 2019h).

Motivasi dan kepuasan peternak berpengaruh positif dan signifikan terhadap pengembangan usaha ternak (Fathurohman dan Sobari, 2016). Peranan Pemerintah Daerah dalam mendukung pengembangan usaha ternak di daerah salah satunya dengan peningkatan kualitas SDM peternak (Suresti et al., 2013), misalnya dengan pelatihan pengolahan produk hasil ternak (Amam dan Harsita, 2017) dan pelatihan pembuatan pupuk organik (Shintara dan Arif, 2016) sebagai upaya untuk mengurangi salah satu permasalahan utama usaha ternak sapi potong di tingkat peternak, yaitu pengelolaan dan pemanfaatan limbah ternak (Harsita dan Amam, 2019). 
Sumber daya fisik dipengaruhi SDM peternak secara positif namun tidak signifikan (taraf signifikansi 5\%), artinya kualitas SDM tidak berperan banyak terhadap sumber daya fisik peternak sapi potong di Desa Petung. Kondisi tersebut disebabkan oleh banyaknya masyarakat Desa Petung yang memelihara ternak sapi potong, namun tidak dilakukan dengan orientasi bisnis, melainkan hanya sebagai tabungan peternak (Soetriono et al., 2019), sebab berkaitan erat dengan sikap dan motivasi peternak (Amam et al., 2016; Harsita dan Amam, 2019). Akses peternak terhadap sumber daya fisik cenderung diperoleh dari bisnis atau pekerjaan lain, seperti pekerjaan utama, usaha pertanian, dan usaha sampingan. Rusdiana dan Praharani (2019) mengemukakan pemerintah perlu mendorong investasi usaha ternak dan melakukan pemberdayaan peternak, sehingga peternak mampu mencapai kelayakan usaha dan pendapatan peternak meningkat. Pemberdayaan peternak yang diwadahi oleh kelembagaan peternakan dapat menekan aspek kerentanan usaha ternak dan meningkatkan posisi daya tawar peternak (Amam dan Solikin, 2020).

\section{KESIMPULAN}

SDM peternak berpengaruh pada akses peternak terhadap sumber daya finansial sebesar 32,4\%, sumber daya teknologi sebesar $35,2 \%$, dan sumber daya fisik sebesar $28,1 \%$. SDM peternak memengaruhi akses terhadap sumber daya finansial dan teknologi secara positif dan signifikan, namun tidak signifikan pada akses terhadap sumber daya fisik.

\section{KONFLIK KEPENTINGAN}

Tim authors menginformasikan bahwa kegiatan Program Pengabdian Desa Binaan (PPDB) ini menggunakan dana hibah internal skim PPDB dari Universitas Jember pada tahun 2019, namun tim peneliti menyatakan bahwa dalam rangkaian penelitian dan penyusunan naskah luaran penelitian tidak memiliki konflik interes dengan pihak manapun.

\section{UCAPAN TERIMA KASIH}

Penelitian ini merupakan bagian dari rangkaian penelitian yang panjang dan berkelanjutan, sehingga melibatkan banyak pihak dalam pelaksanaan penelitian ini. Tim penulis menyampaikan ucapan terimakasih kepada: a) Lembaga Penelitian dan Pengabdian kepada Masyarakat (LP2M) Universitas Jember (UNEJ); b) Kelompok Riset (KeRis) Agribisnis dan Agroindustri Peternakan (A2P) di bawah Laboratorium Sosial Ekonomi Peternakan; c) Mahasiswa Program Studi Peternakan Universitas Jember yang terlibat di dalam project research tahun anggaran 2019-2021; d) Kepala Desa Petung beserta perangkat desa dan masyarakat peternak sapi potong; serta e) Dinas Pertanian Kabupaten Bondowoso, khususnya Bidang Peternakan dan Kesehatan Hewan.

\section{DAFTAR PUSTAKA}

Amam, A. \& P. A. Harsita. 2017. Pengaruh atribut susu bubuk berkalsium tinggi terhadap kepuasan dan loyalitas konsumen. Jurnal Sosial Ekonomi Pertanian. 10(3): 16-22. https://doi.org/10.19184/jsep.v10i3.5680.

Amam, A. \& P. A. Harsita. 2019a. Aspek kerentanan usaha ternak sapi perah di Kabupaten Malang. Agrimor: Jurnal Agribisnis Lahan Kering. $\quad 4(2)$ : 26-28. https://doi.org/10.32938/ag.v4i2.663.

Amam, A. \& P. A. Harsita. 2019b. Efek domino performa kelembagaan, aspek risiko, dan pengembangan usaha terhadap SDM peternak sapi perah. Sains Peternakan: Jurnal Penelitian Ilmu Peternakan. 17 (1): 5-11. https://doi.org/10.20961/sainspet.v17i1.2426 6.

Amam, A. \& P. A. Harsita. 2019c. Pengembangan usaha ternak sapi perah: evaluasi konteks kerentanan dan dinamika kelompok. Jurnal Ilmiah Ilmu-Ilmu Peternakan. 22(1): 23-34. https://doi.org/10.22437/jiiip.v22i1.7831.

Amam, A. \& P. A. Harsita. 2019d. Tiga pilar usaha ternak: breeding, feeding, and management. Jurnal Sain Peternakan Indonesia. 14(4): 431439. https://doi.org/10.31186/ jspi.id.14.4.431-439.

Amam, A. \& S Soetriono. 2019. Evaluasi performa kelembagaan peternak sapi perah berdasarkan aspek risiko bisnis dan pengembangan usaha. 
Jurnal Ilmu dan Teknologi Peternakan Tropis. 5(3):

8-13.

http://dx.doi.org/10.33772/jitro.v6i1.5391.

Amam, A. \& S. Soetriono. 2020. Peranan sumber daya dan pengaruhnya terhadap SDM peternak dan pengembangan usaha ternak di Kawasan Peternakan Sapi Perah Nasional (KPSPN). Jurnal Peternakan Indonesia. 22(1): 1-10. https://doi.org/10.25077/jpi.22.1.110.2020

Amam, A. \& N. Solikin. 2020. The effect of resources on institutional performance and vulnerability aspects of dairy cattle business. EBGC 2019. https://doi.org/10.4108/eai.3-102019.2291919.

Amam, A., M. W. Jadmiko, \& P. A. Harsita. 2020a. Institutional performance of dairy farmers and the impact on resources. Agraris: Journal of Agribusiness and Rural Development Research. 6(1): 63-73. https://doi.org/10.18196/agr.6191.

Amam, A., M. W. Jadmiko, P. A. Harsita, \& M. S. Poerwoko. 2019a. Model pengembangan usaha ternak sapi perah berdasarkan faktor aksesibilitas sumber daya. Jurnal Sain Peternakan Indonesia. 14(1): 61-69. https://doi.org/10.31186/jspi.id.14.1.61-69.

Amam, A., M. W. Jadmiko, P. A. Harsita, \& R. Yulianto. 2019b. Internal resources of dairy cattle farming business and their effect on institutional performance and business development. Journal of Animal Production. 21(3): 157-166. http://doi.org/10.20884/1.jap.2019.21.3.738.

Amam, A., M. W. Jadmiko, P. A. Harsita, N. Widodo, \& M. S. Poerwoko. 2019c. Sumber daya internal peternak sapi perah dan pengaruhnya terhadap dinamika kelompok dan konteks kerentanan. Jurnal Ilmiah Peternakan Terpadu. 7(1): 1-8. http://dx.doi.org/10.23960/jipt.v7i1.p192200.

Amam, A., M. W. Jadmiko, P. A. Harsita, R. Yulianto, N. Widodo, Soetriono, \& M. S. Poerwoko. 2020b. Usaha ternak sapi perah di Kelompok Usaha Bersama (KUB) Tirtasari Kresna Gemilang: Identifikasi sumber daya dan kajian aspek kerentanan. Jurnal Ilmu Peternakan dan Veteriner Tropis. 10(1): 77-86. https://doi.org/10.30862/jipvet.v10i1.

Amam, A., R. Yulianto, N. Widodo, \& S. Romadhona. 2020c. Pengaruh aspek kerentanan terhadap aksesibilitas sumber daya usaha ternak sapi potong. Livestock and Animal Research. 18(2): 97-107. https://doi.org/10.20961/lar.v18i2.42955.

Amam, A., Z. Fanani, \& B. A. Nugroho. 2016. Analisis sikap konsumen terhadap susu bubuk berkalsium tinggi dengan menggunakan multi-atribut model dan norma subyektif model. Wacana: Jurnal Sosial dan Humaniora. 19(2): 12-21. http://dx.doi.org/10.21776/ub.wacana.2016.0 19.01.2.

Amam, A., Z. Fanani, B. Hartono, \& B. A. Nugroho. 2019d. Broiler livestock business based on partnership cooperation in Indonesia: The assestment of opportunities and business development. International Journal of Entrepreneurship. 23(4): 1-10.

Amam, A., Z. Fanani, B. Hartono, \& B. A. Nugroho. 2019e. Identification on resources in the system of broiler farming business. Jurnal Ilmu Ternak dan Veteriner. 23(4): 135-142. http://dx.doi.org/10.14334/jitv.v24.3.1927.

Amam, A., Z. Fanani, B. Hartono, \& B. A. Nugroho. 2019f. Identifikasi sumber daya finansial, teknologi, fisik, ekonomi, lingkungan, dan sosial, pada usaha ternak ayam pedaging. Prosiding Seminar Nasional Teknologi Peternakan dan Veteriner. 438-746. http://dx.doi.org/10.14334/Pros.Semnas.TPV -2019-p.738-746.

Amam, A., Z. Fanani, B. Hartono, \& B. A. Nugroho. 2019g. Pengembangan usaha ternak ayam pedaging sistem kemitraan bagi hasil berdasarkan aksesibilitas peternak terhadap sumber daya. Jurnal Ilmu dan Teknologi Peternakan Tropis. 6(2): 146-153. http://dx.doi.org/10.33772/jitro.v6i2.5578.

Amam, A., Z. Fanani, B. Hartono, \& B. A. Nugroho. $2019 \mathrm{~h}$. The power of resources in independent livestock farming business in Malang District, Indonesia. IOP Conferences Series: Earth and Environmental Science. 372: 1-10. http://doi.org/10.1088/17551315/372/1/012055.

Amam, A., Z. Fanani, B. Hartono, \& B. A. Nugroho. 2019i. Usaha ternak ayam pedaging sistem kemitraan pola dagang umum: pemetaan sumber daya dan model pengembangan. Sains Peternakan: Jurnal Penelitian Ilmu Peternakan. 17(2): 5-11. https://doi.org/10.20961/sainspet.v17i2.2689 2. 
Arifin, M. Z. \& R. Riszqina. 2016. Analisis potensi pengembangan ternak sapi potong melalui pendekatan lahan dan sumber daya manusia di Kecamatan Galis Kabupaten Pamekasan. Maduranch: Jurnal Ilmu Peternakan. 1(1): 112.

Ashary, L. 2016. Pengaruh praktek manajemen sumber daya manusia terhadap produktivitas karyawan peternak ayam potong PT Mitra Gemuk Bersama (MGB) di Kabupaten Jember. Jurnal Ekonomi dan Bisnis Growth. 14(2): 72 82.

Fathurohman, F. \& F. Sobari. 2016. Strategi pengembangan kinerja SDM gugus perwakilan pemilik ternak SPR Cinagarabogo Subang (tinjauan teori dan aplikasi). Dimensia: Jurnal Kajian Sosisologi. 13(2): $67-$ 92.

Harsita, P. A. \& A. Amam. 2019. Analisis sikap konsumen terhadap produk olahan singkong. Agrisocionomics: Jurnal Sosial Ekonomi dan Kebijakan Pertanian. 3(1): 19-27. https://doi.org/10.14710/

agrisocionomics.v3i1.2469.

Harsita, P. A. \& A. Amam. 2019. Permasalahan utama usaha ternak sapi potong di tingkat peternak dengan pendekatan Vilfredo Pareto Analysis. Prosiding Seminar Nasional Teknologi Peternakan dan Veteriner. 241-250. http:/ / dx.doi.org/10.14334/Pros.Semnas.TPV -2019-p.241-250.

Qinayah, M., Hastang, \& S. N. Sirajuddin. 2017. Tingkat pendapatan peternak sapi potong pada skala usaha yang berbeda di Desa Mattirowalie Kecamatan Tanete Riaja Kabupaten Barru. Seminar Nasional Peternakan 3 tahun 2017 September 18: Makassar, Indonesia.

Rusdiana, S. \& L. Praharani. 2019. Pengembangan peternakan rakyat sapi potong: kebijakan swasembada daging sapi dan kelayakan usaha ternak. Forum Penelitian Agro Ekonomi. $\quad 36(2)$ : 97-116. http:/ / dx.doi.org/10.21082/fae.v36n2.2018.97 -116 .

Rusdiana, S., U. Adiati, \& R. Hutasoit. 2016. Analisis ekonomi usaha ternak sapi potong berbasis agroekosistem di Indonesia. Agriekonomika: Jurnal Sosial Ekonomi dan Kebijakan Pertanian. 5(2): 137-149. http://dx.doi.org/10.21107/agriekonomika. v5i2.1794.

Setiawan H. M., B. Hartono, \& H. D. Utami. 2014. Kontribusi pendapatan usaha ternak sapi potong terhadap rumah tangga peternak. Jurnal Fakultas Peternakan Universitas Brawijaya. https://fapet.ub.ac.id/wpcontent/uploads/2014/06/JURNALKU.pdf.

Shintara, G. A. \& S. Arif. 2016. Pengelolaan pelatihan pembuatan pupuk organik bagi remaja putus sekolah di Pampung Plumbon Karanganyar. Jurnal Manajemen Pendidikan. 11(2): 60-68. https://doi.org/10.23917/jmp.v11i1.1827.

Soetriono, S. \& A. Amam. 2020. The performance of institutional of dairy cattle farmers and their effect on financial, technological, and physical resources. Jurnal Ilmu-Ilmu Peternakan. 30(2): 128-137.

https://doi.org/10.21776/ub.jiip.2020.030.02. 05.

Soetriono, S., D. Soejono, D. B. Zahrosa, A. D. Maharani, \& A. Amam. 2019. Strategi pengembangan dan diversifikasi sapi potong di Jawa Timur. Jurnal Ilmu dan Teknologi Peternakan Tropis. 6(2): 138-145. http://dx.doi.org/10.33772/jitro.v6i2.5571.

Sunarto, E., O. H. Nono, U. R. Lole, \& Y. L. Henuk. 2016. Kondisi ekonomi rumah tangga peternak penggemukan sapi potong pada peternakan rakyat di Kabupaten Kupang. Jurnal Peternakan Indonesia. 18(1): 21-28. https://doi.org/10.25077/jpi.18.1.21-28.2016.

Suresti, A., R. Wati, \& I. Indrayani. 2013. Analisis potensi sumber daya manusia untuk pengembangan usaha peternakan sapi potong di Kabupaten Pesisir Selatan. Jurnal Peternakan Indonesia. 15(1): 7-16. https://doi.org/10.25077/jpi.15.1.7-16.2013.

Widiati, R. 2014. Membangun industri sapi potong rakyat dalam mendukung kecukupan daging sapi. Wartazoa. 24(4): 91-200. http://dx.doi.org/10.14334/wartazoa.v24i4.1 090.

Wiyono, G. 2011. Merancang Penelitian Bisnis dengan alat analisis SPSS 17.0 \& SmartPLS 2.0. Penerbit: Unit Penerbit dan Percetakan STIM YKPN. Yogyakarta. 